\title{
Ecodomy in mission: The ecological crisis in the light of recent ecumenical statements
}

\begin{tabular}{|c|c|}
\hline \multicolumn{2}{|c|}{$\begin{array}{l}\text { Author: } \\
\text { Cornelius J.P. Niemandt }{ }^{1}\end{array}$} \\
\hline \multicolumn{2}{|c|}{$\begin{array}{l}\text { Affiliation: } \\
{ }^{1} \text { Department Science of } \\
\text { Religion and Missiology, } \\
\text { University of Pretoria, } \\
\text { South Africa }\end{array}$} \\
\hline \multicolumn{2}{|c|}{$\begin{array}{l}\text { Correspondence to: } \\
\text { Cornelius Niemandt }\end{array}$} \\
\hline \multicolumn{2}{|c|}{$\begin{array}{l}\text { Email: } \\
\text { nelus.niemandt@up.ac.za }\end{array}$} \\
\hline \multicolumn{2}{|c|}{$\begin{array}{l}\text { Postal address: } \\
\text { Private Bag X20, Hatfield } \\
0028 \text {, South Africa }\end{array}$} \\
\hline \multicolumn{2}{|c|}{$\begin{array}{l}\text { Dates: } \\
\text { Received: } 22 \text { Feb. } 2015 \\
\text { Accepted: } 29 \text { July } 2015 \\
\text { Published: } 30 \text { Sept. } 2015\end{array}$} \\
\hline \multicolumn{2}{|c|}{$\begin{array}{l}\text { How to cite this article: } \\
\text { Niemandt, C.J.P., 2015, } \\
\text { 'Ecodomy in mission: The } \\
\text { ecological crisis in the } \\
\text { light of recent ecumenical } \\
\text { statements', Verbum et } \\
\text { Ecclesia } 36(3) \text {, Art. \#1437, } \\
8 \text { pages. http://dx.doi. } \\
\text { org/10.4102/ve.v36i3.1437 }\end{array}$} \\
\hline \multicolumn{2}{|c|}{$\begin{array}{l}\text { Note: } \\
\text { This article represents a } \\
\text { theological reflection on the } \\
\text { Faculty Research Theme (FRT) } \\
\text { of the Faculty of Theology, } \\
\text { University of Pretoria, entitled } \\
\text { 'Ecodomy - Life in its fullness'. } \\
\text { The theme is portrayed from } \\
\text { the perspective of various } \\
\text { theological disciplines. } \\
\text { A conference on this theme } \\
\text { was held on } 27-28 \text { October } \\
2014 .\end{array}$} \\
\hline \multicolumn{2}{|c|}{$\begin{array}{l}\text { Copyright: } \\
\text { (C) 2015. The Authors. } \\
\text { Licensee: AOSIS } \\
\text { OpenJournals. This work is } \\
\text { licensed under the Creative } \\
\text { Commons Attribution } \\
\text { License. }\end{array}$} \\
\hline \multicolumn{2}{|l|}{ Read online: } \\
\hline 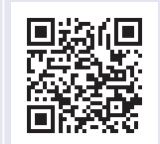 & $\begin{array}{l}\text { Scan this QR } \\
\text { code with your } \\
\text { smart phone or } \\
\text { mobile device } \\
\text { to read online. }\end{array}$ \\
\hline
\end{tabular}

This research explored ecodomy in mission and gave a brief overview of the ecological dimension of mission. This was done in terms of the polarity between creation and end times, or a creation-centred and a redemption-centred approach. The two approaches were described by focusing on two themes found in the works of missiologist and ecumenical policy documents (The Accra Confession, The Cape Town Commitment, and Together towards lifeMission and evangelism in changing landscapes): the reorientation towards creation and the re-imagination of the eschaton. In terms of the reorientation towards creation, the research found that current developments in missiology reflect a major interest in the importance of ecological issues, offer a clear understanding that the Gospel is good news for all of creation, and demand justice towards the whole oikoumene. It affirmed that God's mission is inherently creational and world-affirming. In terms of the re-imagination of the eschaton, the research found that the new life promised by the gospel is life in fullness, and includes the whole oikoumene. The reality that is already present in the reign of the risen Christ in his kingdom, structures and informs the life-giving mission of the church.

\section{Introduction}

Pope Francis issued an important environmental encyclical - Laudato Si' - on care for the creation on 24 May 2015 (Francis 2015). The encyclical is addressed to the people of the world and the pope invites the people to urgently address the ecological crisis 'about our common home' (Francis 2015:5). He (Francis 2015) pointed out that:

The urgent challenge to protect our common home includes a concern to bring the whole human family together to seek a sustainable and integral development, for we know that things can change. (p. 4)

This immense and urgent challenge (Francis 2015:5) added another important voice to recent important ecumenical documents and statements, and a missiological discourse that was already voiced by David Bosch (1995) in one of his very last publications, Believing in the future, where he identified 'ecological damage' (Bosch 1995:3) as one of the characteristics of the First World. He defines mission as alerting people to the universal reign of God (Bosch 1995:33). The call to faith must help people to articulate an answer to the question: 'What do we have to become Christians for?' - to which he gives the partial answer: 'In order to be enlisted into God's ministry of reconciliation, peace and justice on earth' (Bosch 1995:34), which, from his argument, includes paying attention to the ecological damage brought about by Western subjugation and exploitation of nature (Bosch 1995:55). Most importantly, and in a manner that reminds us of Bosch's emerging paradigms of post-modern mission as espoused in Transforming Mission (Bosch 1991), he identifies a number of elements of a missiology of Western culture. The very first element is an ecological dimension, because the time is long past to exclude the environment from the missiological agenda.

This research explores ecodomy in mission, the growing attention to earthkeeping and life in fullness in missiology. ${ }^{1}$ The concept ecodomy can be understood in terms of Laudato Si' as care for our common home, and refers to the sustainable and integral development of the whole of creation, as well as the development of an integral ecology. It focuses on life in fullness, and is a 'celebration of creation and fruitfulness overflowing from the love of God', and the 'restoration of the whole creation' (Keum 2013:37). In terms of the policy document of the World Council of Churches (WCC), life in fullness is a genuine freedom that is allied with the renewal of the natural world and justice in the economy (Keum 2013:46). It is related to the important issue of climate change, and shares Francis' (2015:7) conviction that the climate is a common good, belonging to all and meant for all. At a global level, climate refers to the complex system linked to many of 1.This research was written against the background and as part of the Faculty of Theology at the University of Pretoria's Faculty Research
Theme 'Oikodome: Life in its fullness'. The concept 'Oikodome' will be discussed and unpacked in research published in the current issue of Verbum et Ecclesia, and this research reflects a missiological contribution to the development and content of Oikodome. 
the essential conditions for human life. Ecodomy is broader than climate, but includes the term. The term 'ecodomy' is closely related to oikoumene [the inhabited world and a term integrally linked with mission], oikein [to inhabit] and oikia [house or dwelling] (Conradie 2013:18-19).

This research will be done within the framework of investigating the attention to ecological matters, especially in terms of the polarity between 'creation' and 'end times', in three important recent missiological ecumenical documents: The Accra Confession (2004), The Cape Town Commitment (2010), and Together towards life - Mission and evangelism in changing landscapes of the WCC (Keum 2013). The framework is constructed keeping in mind Bevans (1992:16) in his description of two theological orientations in the contextualisation of theology - a creation-centred and a redemption-centred approach. In the creationcentred approach, the world is seen as sacramental and a place where God reveals himself. The redemption-centred approach views culture and human experience as in need of transformation, or even total replacement. This article keeps the tension between both approaches alive, and tries to postulate an approach where keeping both in creative tension creates new opportunities to re-imagine missiology (see also Conradie 2006:268) and to place ecodomy. It can be labelled a synthesis, in terms of Kritzinger and Saayman's (2011:150 151) description of Bosch's approach as a synthetic model that requires one to keep a number of elements in creative tension.

This will be done in a manner that reminds us of Bosch's open-ended, multi-dimensional approach to mission (Kritzinger 2011:34), namely that there are a number of paradigms operating in missiology. Although Bosch did not discuss mission as earthkeeping in Transforming Mission, missiologists such as Bevans and Schroeder (2004) added a commitment to the integrity of creation as one of the components of missiology.

An important clue to the approach followed in this article can be found in turning the concept of 'inculturation' on its head. Taking the missio Dei seriously is to start with the incarnation of Christ (see also Hastings 2012:loc.1801). The incarnation of Christ was a moment of 'increation': he became flesh. The sending of God is a sending to the world, to the totality of creation. DeWitt (2008) says:

The Word incarnate, expressing God's profound love for the world (Jn 3:16-17) comes liturgically into the sanctuary and the Holy Eucharist, moves into creation to open the shackles of enslaved peoples and creation, breaks the chains of sin, oppression, degradation, and bondage, and renews the life of the earth. Jesus Christ - the hope of the world. (p. 92)

God's mission encompasses the cosmos; therefore Christian mission includes all of God's created order - the whole ecodomy. Missiology must assist theology to discern the visceral reality of our material world and our part in it. To put it differently: the focus of a missional church must be creation bound, for the true missional church will be an organic or ecological church (Niemandt 2011:73).

\section{Reorientation towards creation}

For many years, mission was understood as the actions of the church that began with the events during Pentecost, i.e. the outpouring of the Spirit and the establishment of the church. In a certain sense, the famous threefold goal of mission, formulated by Gisbertus Voetius, namely: the conversion of Gentiles, the planting of the church, and the glory and manifestation of God's grace (Kritzinger, Meiring \& Saayman 1994:1), captured the imagination of missiologists and the church for centuries. Much of this can be seen in definitions of mission, such as the strong focus of, for example, the Lausanne movement, on evangelism. Evangelism is described as primary in the church's mission of sacrificial service. Even the so-called 'holistic approach' that developed later, with its focus on kerugma, diakonia, koinonia and leitourgia (Kritzinger et al. 1994:36-39), failed to include an orientation towards the creation event and ecodomy. It is a pity that Kritzinger (1991:16) did not develop his plea that 'missionaries should become involved with environmentalists in the salvation of our planet' in his later works on mission. Skreslet's (2012) important work on the history of missiology also has very scant reference to the importance of 'eco-theology', with nothing but a brief reference to the spiritual legacy of St. Francis and his remarkable concern for God's creation (Skreslet 2012:loc.4055). Although Skreslet (2012:loc.388) defines missiology as 'the systematic study of all aspects of mission', and although he is very clear on the importance of conducting the study of mission with multiple methodologies, he does not include 'eco-theology', earthkeeping or 'ecodomy' in his 'themes in mission'. Bevans and Schroeder (2004:375), in their very comprehensive and important theology of mission, also acknowledge that the preservation of the integrity of creation has not received much attention in the church's mission.

But, in recent years, missiology and the understanding of mission have moved completely away from such a narrow approach, with the point of departure now being the understanding that God's mission includes the whole of creation. Mission is 'all that God is doing in his great purpose for the whole of creation', and all that he calls his people 'to do in cooperation with that purpose' (Wright 2010:24). The church's mission is to participate in God's mission to restore the whole of creation and all of human life. The scope of salvation is as broad as creation, and this must also be evident in missiology (see Goheen 2014:248).

It is important here to appreciate the departure made from earlier concepts of mission by Johannes Hoekendijk. After the missionary conference in Willingen, two foci can be observed (Van Gelder \& Zscheile 2011:30): 'redemption' that is 'specialised' through the church's role as the principle channel by which God's redemption occurs in the world, and 'creation' that has a broader perspective of God's desire to continue to care for his creation. Hoekendijk (1950:168) was concerned about missions' overemphasis on church growth, and argued that mission focused only on the church stands in juxtaposition to mission focused on the kingdom of God. 
He argued that the world, not the church, is the core of God's mission. For him, the church is never the subject of mission at most it is a partner in the missio Dei (see also Flett 2010:44). This leads to an 'apostolate theology', where the church is perceived primarily in its relationship with the world. The gospel and the apostolate belong together, in the sense that God continues to struggle for the sake of the world (Flett 2010:52). For Hoekendijk (1950:168), shalom was the guiding principle - it describes the true objective of the church's work in the present (see also Skreslet 2012:loc.816). Skreslet (2012:loc.1655) argues for Hoekendijk's approach and says that shalom stands not only for the divine future vision of an ideal social order, but also for God's desire that peace and harmony be restored throughout creation.

Reference to a number of missiologists will illustrate this important shift in missiology. Although the illustrations are obviously not comprehensive, they still serve to show the emergence of a new theme in missiology.

Reference has been made to the remarks of Bosch. Although the issue of ecology did not surface in Transforming mission, it was the very first issue mentioned in Believing in the future (Bosch 1995). This recognition of the insight that God's redemptive mission includes creation was, up to then (with the exception of Hoekendijk's broad apostolate theology), not part and parcel of most mainstream missiologies. ${ }^{2}$

In Constants in context, Bevans and Schroeder (2004:348) acknowledge the influence of Bosch and the importance of Transforming mission, but endeavour to go beyond Bosch. They also use a multi-dimensional approach to mission, and synthesise mission as prophetic dialogue. They then proceed to formulate six dimensions of mission as prophetic dialogue'essential components of God's mission in which the church is called to share' (Bevans \& Schroeder 2004:351). The six are:

- witness and proclamation

- liturgy, prayer, and contemplation

- justice, peace, and the integrity of creation

- inter-religious dialogue

- inculturation

- reconciliation.

Bevans and Schroeder (2004:376) state that mission witnesses to, proclaims, celebrates, and works for a new way of thinking about and seeing human beings, earth's creatures, and the created universe itself. Ecological justice entails issues such as a lifestyle that uses fewer of the world's resources, church support for legislation that enhances the sustainability of the environment, the development of organic farming, and the protection of wildlife areas. These kinds of commitments demand prophetic living, prophetic speech and prophetic action. The point is that gospel salvation includes human well-being and the well-being of all of creation (Bevans \&

2.One must mention, however, the early work of Jannie du Preez (Reading three 'enthronement psalms'), Jimmy Loader (Life, wonder and responsibility: Some thoughts on ecology and Christian mission), Piet Meiring (The Greens - Avant-garde missionaries), and L.D. Hulley (Justice, peace and the integrity creation: Some ethical comments), all published in Missionalia 19 (1991).
Schroeder 2004:377). In a later publication (Prophetic dialogue: Reflections on Christian mission today), Bevans and Schroeder (2011:67) say that responsibility towards the earth is a crucial part of the church's mission.

The work of Walls and Ross (2008) is also important here, because it represents a migration away from exclusive Western influences on missiology, to a new landscape of global mission (Walls \& Ross 2008:xii). They describe the five marks of global mission, in conversation with Bevans and Schroeder's (2004) Constants, of the Christian faith. They mention proclamation, teaching, loving service, and the transformation of unjust structures in society, but also include 'to strive to safeguard the integrity of creation and to sustain and renew the life of the earth' (Walls \& Ross 2008:84). One must note here the formulation and the focus on the 'life of the earth', as this theme of life emerges later in ecumenical documents as well. In his contribution to the work, edited by Walls and Ross, DeWitt (2008:85) takes great care to describe the 'oikoumene of God'. Referring to Eastern Orthodox theology, theology is defined as the study and examination of the whole work of Divine Oikonomy - from the creation of the world until the last times - realised by the church within history and time. He formulates (DeWitt 2008:89) four principles for the stewardship of creation:

- The conservancy principle: We should return the service of creation to us with service of our own.

- The safeguarding principle: We should safeguard the Lord's creation as the Lord safeguards us.

- The fruitfulness principle: We should enjoy the fruit of creation, but not destroy its fruitfulness.

- The Sabbath principle: We should provide for creation's Sabbath rest with no relentless pressing.

Christopher J.H. Wright can be seen as a representative of evangelical missiologists, as he played an important role in Lausanne III in Cape Town in 2010. He (Wright 2010:49) states that God will hold us accountable for our humanity as much as for our Christianity. This has a profound impact on the understanding of mission, as both the creation and redemption of creation by the Triune God is part and parcel of God's gospel at work in history and creation. In The mission of God, he (C.J.H. Wright 2006:403) states that the whole earth is the field of God's mission. When Wright (2010:112) answers the question on what the mission of God's people is, he says that at least part of the answer is that the people of God must be signposts to the ultimate liberation of all creation and humanity from every form of oppression and slavery. Environmental action is therefore a legitimate and integral dimension of biblical mission. He (Wright 2010:112) concludes: 'As Christian human beings, therefore, we are doubly bound to see active care for creation as a fundamental part of what it means to love and obey God'.

The importance of creation and 'ecodomy' can be seen in his statement (Wright 2010):

Creation is not just the disposable backdrop to the lives of human creatures who were really intended to live somewhere else, and 
some day will do so. We are not redeemed out of creation, but as part of the redeemed creation itself - a creation that will again be fully and eternally for God's glory, for our joy and benefit, and forever. (p. 56)

Wright (2010:267) says that ecologically responsible behaviour is an integral facet of the church's mission and part of Christian discipleship.

Timothy C. Tennent is another important evangelical voice. He (Tennent 2010:loc.1914) argues that the biblical witness is framed by God's creation of the heavens and the earth $(\mathrm{Gn}$ 1 ), and the account of the new heaven and the new earth ( $R v$ 21). This implies that all of human history and culture and engagement with nature (today we can say all of the 'ecodomy') falls within the parameters of God's creative and sustaining acts. Central to Tennent's (2010:loc.1930) understanding of the missio Dei is that God has taken the initiative to act on behalf of the redemption of the entire world (Tennent 2010:loc.1925). The ultimate purpose of the Triune God is to draw the entire cosmos into communion with God's divine life.

\section{Ecological mission in ecumenism}

There is a rapid, significant and often spontaneous movement towards ecological mission around the world (Bookless 2008:97). This can be seen in the main Christian tradition, and is especially clear in the ecumenical movement. A brief overview of ecumenical meetings since 2004 shows the unequivocal commitment to ecological justice issues. The Accra Confession, adopted by the delegates of the World Alliance of Reformed Churches' (WARC 2004) 24th General Council in Accra, Ghana, recognises that:

... current economic doctrines, with the traditional Reformed criticism of idols (i.e., Mammon, consumerism, the financial and speculative markets), deny God's life-giving sovereignty and defy God's covenant by excluding the poor, the vulnerable, and the whole of Creation from the fullness of life. (p. 3)

As an introduction to the eventual adopted confession, the document speaks about 'reading the signs of the times', and that they (WARC 2004) ${ }^{3}$ :

\begin{abstract}
... have heard that creation continues to groan, in bondage, waiting for its liberation ( $R \mathrm{~m} 8: 22$ ). We are challenged by the cries of the people who suffer and by the woundedness of creation itself. We see a dramatic convergence between the suffering of the people and the damage done to the rest of creation. (p. 1)
\end{abstract}

In one of the plenary sessions of the Cape Town 2010 meeting of the Lausanne Movement, Newman stated that Christians are believers in a Creator and a Redeemer God, and hence have 'a great responsibility to act on God's behalf in our

3.The Edinburg World Mission Conference 2010 also linked social justice issues to ecological justice issues, stating that the cry of the poor is the same as the cry of the ecological justice issues, stating that the cry of the poor is the same as the cry of the earth. Just as the poor buckle under the heavy yoke of unjust economic policies and practices, the earth is buckling under the weight of massive degradation and wanton destruction carried out in the name of progress and development. The Edinburg World Mission Conference 2010 called on churches to become communities of compassion and healing, 'where there is a new zeal for justice, peace, and the protection of the environment, and renewed liturgy reflecting the beauties of the Creator and creation' (Edinburgh World Mission Conference 2010). world today' (Laferton 2010:1). The concept of 'integral mission' assisted the Lausanne movement to progress to a more comprehensive understanding of mission. In the Cape Town Commitment, it is stated that (Lausanne III 2011):

Integral mission means discerning, proclaiming, and living out the Biblical truth that the gospel is God's good news, through the cross and resurrection of Jesus Christ, for individual persons, and for society, and for creation. All three are broken and suffering because of sin; all three are included in the redeeming love and mission of God; all three must be part of the comprehensive mission of God's people. (p. 13)

The design of the declaration consists of a number of issues demanding the love of God's people (i.e.: we love the living God, we love God's Word, we love the gospel of God, and we love the people of God). Lausanne III clearly states its love for the world of God's creation. This love is not sentimental affection for nature, but is described as the logical outworking of 'our love for God by caring for what belongs to him' (Lausanne III 2011:13). As is further explained in the document (Lausanne III 2011):

This must be done in a way that cares for the earth and all its creatures, because the earth belongs to God, and for the sake of Jesus Christ who is the Creator, Owner, Sustainer, Redeemer, and Heir of all creation. (p. 29)

Lausanne III warns against the 'toxicidolatry of consumerism', and calls on Christians to repent their part in the destruction, waste and pollution of the earth's resources. In the summary of commitments, the document (Lausanne III 2011) states:

We commit ourselves to the integral and dynamic exercise of all dimensions of mission to which God calls his Church. God commands us to reflect his own character through compassionate care for the needy, and to demonstrate the values and the power of the kingdom of God in striving for justice and peace and in caring for God's creation. (p. 20)

In the discussion of God's peace, Lausanne III (2011:29) describes Christ's peace for his suffering creation. It contains a lament over the widespread abuse and destruction of the earth's resources, including its bio-diversity, and identifies climate change as the most serious challenge.

The 10th Assembly of the WCC (Keum 2013) received a new mission affirmation: Together towards life: Mission and evangelism in changing landscapes (TTL). This affirmation was unanimously approved by the WCC Central Committee held in Crete, Greece, on 05 September 2012. The mission affirmation is set in the context of God's creation and the whole oikoumene, with a clear emphasis on the broad issue of 'life'. The affirmation (Keum 2013) states:

Rather the gospel is the good news for every part of creation and every aspect of our life and society. It is, therefore, vital to recognize God's mission in a cosmic sense, and to affirm all life, the whole oikoumene, as being interconnected in God's web of life. (p. 5)

It is significant to note that mission is understood as being all about the flourishing of creation (Keum 2013:9-11). The 
WCC called on churches to move beyond a narrowly humancentred approach and to focus on the reconciled relationship with all created life. This affirmation presented an interesting understanding of the missio Dei: participation in God's mission is understood as participation in communion with all of creation (Keum 2013:38).

In the conclusion of TTL, the document states a number of affirmations that summarise the whole document. The importance of ecological justice issues is evident in the following affirmations (Keum 2013:37-40):

- 'We affirm that mission begins with God's act of creation and continues in re-creation ...'

- 'We affirm that the mission of God's Spirit is to renew the whole creation'.

- 'Mission, then, is to denounce the economy of greed and to participate in and practice the divine economy of love, sharing and justice'.

- In the affirmation on mission movements from the global south and east, it is stated that 'our mission practice should show solidarity with suffering peoples and harmony with nature'.

In the final affirmations, the document clearly stated that '[ $m$ ] ission has creation at its heart' (Keum 2013:38). Coorilos (2014:42) labels TTL as a creation-centred missiology, and says: 'Mission, therefore, is to turn to God in creation' (Coorilos 2014:43).

TTL also has a whole section on the theme of 'Mission and the flourishing of creation' (Keum 2013:9-11). This section describes the relation between the missionary God, the creation of life, and the church's calling to participate in God's life-giving mission. It states clearly that mission begins with the act of creation, and calls on the church to embrace forms of mission that express our reconciled relationship with all created life. In practical terms, TTL calls on churches to campaign for eco-justice, more sustainable lifestyles, and the development of spiritualities that are respectful of the earth.

When one evaluates the TTL document, it is immediately apparent that it does have a very clear focus on the relationship with creation and life in all its fullness. The scope and intention of the TTL document can be seen in the formulation of the introduction of the theme (Keum 2013):

We believe in the Triune God who is the Creator, Redeemer, and Sustainer of all life. God created the whole oikoumene in God's image and constantly works in the world to affirm and safeguard life. (p. 4)

Our conference theme of life in its fullness is also emphasised in the very next statement (Keum 2013):

God invites us into the life-giving mission of the Triune God and empowers us to bear witness to the vision of abundant life for all in the new heaven and earth. (p. 4)

Later on it says that 'the church is commissioned to celebrate life, and to resist and transform all life-destroying forces'
(Keum 2013:4). 'The mission of the church is to prepare the banquet and to invite all people to the feast of life' (Keum 2013:37). Mission is undergirded by a transformative spirituality, and this kind of mission spirituality must motivate the church to serve God's economy of life (Keum 2013:13). TTL does have a very strong pneumatological orientation, and the work of the Spirit in this life-giving mission of God is explained as (Keum 2013:4): 'Life in the Holy Spirit is the essence of mission, the core of why we do what we do and how we live our lives'.

It should also be noted that another policy document, tabled at the WCC in 2013, The Church (TC), also refers to this aspect of mission (WCC 2013):

The Church, as the body of Christ, acts by the power of the Holy Spirit, to continue this life-giving mission in prophetic and compassionate ministry and so participates in God's work of healing a broken world. (p. 8)

The understanding of the Church and its mission is rooted in God's great design for the oikoumene - the economy of all creation. The church is on a life-giving mission and so 'participates in God's work of healing a broken world' (WCC 2013:8).

Noort (2013:194) is correct in his observation that 'the emphasis on life-affirming mission is of crucial significance for TTL'. The mission statement claims that the Spirit of God is at work where life is affirmed and blossoms. As such, the affirmation of life is a criterion to be able to distinguish between the spirits of this world and the Spirit of God, serving as an instrument to observe where God's Spirit is at work. The affirmation thereby also establishes a theological bridge between the Christian faith, secular worldviews, indigenous religions and wisdom traditions, for - because the gospel is good news for all of creation - it is vital to recognise God's mission in a cosmic sense and to affirm all life, the whole oikoumene, as being interconnected in God's web of life (Keum 2013:5). This also represents an important point of critique on TTL: the hermeneutical key, namely that the Spirit is at work where life is affirmed and blossoms, begs the question of how this is reconciled with the classical point of view that the Spirit always points towards Jesus the Christ (see e.g. the Lausanne Movement and the Cape Town 2010 declaration - Lausanne III 2011:10).

\section{Summation}

Kritzinger (2011:47) refers to a seminar held at UNISA, where Roger Schroeder explained their understanding of 'prophetic dialogue'. Prophetic corresponds with the already of the reign of God, and dialogue with the not yet. The already orientation is towards the creation, and prophetic mission calls on the people of God to act as caretakers of God's creation. Dialogue orientates towards the not yet, and brings God's preferred future into the discussion.

Concluding the discussion of ecological justice issues then, the issues tabled and decisions made clearly reflect a major 
interest in the importance of ecological issues, offer a clear understanding that the Gospel is good news for all of creation, and demand justice towards the whole oikoumene. It affirms that God's mission is inherently creational and world-affirming, and carried out by the church as a sign of a new humanity and servant in the kingdom of God, for the recreation of the cosmos (Hastings 2012:loc.306).

\section{Re-imagination of the eschaton}

The incarnation of Christ is very important as a moment of 'increation'. It has already been mentioned that the sending of God is a sending to the world, and to the totality of creation. It is equally important to see the incarnation as the inauguration of the eschaton. In the incarnation, the new creation breaks into the present order (Tennent 2010:2001). This new creation is a new kind of world with a profound kind of physicality - in the words of N.T. Wright (2006:75): a world 'which will be more physical, more solid, more utterly real, a whole in which the physical reality will wear its deepest meaning on its face'. In Surprised by Scripture, Wright (2014) says:

Jesus is not far away; he is in heaven, and heaven is not a place in the sky, but rather God's dimension of what we think of as ordinary reality. (p. 96)

In this section, the focus will be on the other side of the creation-eschaton polarity, namely the eschaton. The article will explore 'ecodomy' and 'eco-theology' from the focus on these issues in terms of a missiological understanding of the eschaton and the implications of God's mission as the remaking of his creation of space, time and matter as a new creation that started with the resurrection of Jesus Christ.

In his multi-dimensional approach to mission, Bosch (1991:498) described mission as 'action in hope'. For him, this entails a recovery of eschatology, but then not in the way of the extreme eschatologisation of mission, as found in the boundless pessimism (Bosch 1991:504) of Protestant orthodoxy, Pietism and, can I add, Pentecostalism. Mission must be future-directed and orientated to the here and now. There is an intrinsic relationship between hope and eschatology, and this must be linked to the kingdom and reign of God. One of the implications of linking hope to eschatology and the kingdom of God is that it highlights the difference between eschatology and teleology. Teleology assumes the steady progress to some future goal or purpose. Eschatology brings together the past and future into the present in a new creation. In this 'action in hope' it is more important to ask about the Christian's involvement in the world rather than seeking to know God's future plan (Niemandt 2011:78).

Robinson (1991:151) argued the case to understand salvation as the restoration of all mankind's relations, including its relationship to nature. The perspective of God's present and future kingdom gives focus to the church's mission agenda (Robinson 1991:151): 'Mission is this new community in the service of God's salvic purpose for all of creation'.
Bevans and Schroeder (2004:377) emphasised that an ecological consciousness in mission stretches the notion of salvation to include the well-being of all of creation. This commitment to human and cosmic welfare has an eschatological dimension that is both already being realised and yet to reach its fulfilment (Bevans \& Schroeder 2004:378). The future, also in terms of the integrity of God's creation, is what we make of it now.

C.J.H. Wright (2006) pays considerable attention to the importance of 'mission and God's earth' in his The mission of God. He uses the concept of the 'fullness of the earth' and describes it as a feature of the creation narrative (C.J.H. Wright 2006:405). This is a way of talking about the whole rich abundance of created order. Wright bases the imperative to care for God's creation on a strong doctrine of creation. However, 'you cannot drive a car looking only in the rearview mirror' (C.J.H. Wright 2006:407). We must thus also value the earth in terms of its ultimate destiny. We need an eschatological foundation to ourecological ethics and missionas such, a biblical hope adds an important dimension to our ecological mission.

Tennent (2010:loc.5611) pays considerable attention to the issue of the 'new creation' in missiology, and calls for the reconnection of our understanding of mission with the larger context of the in-breaking of God's new creation. 'Missions is about extending the claims and realities of the New Creation into the present order' (Tennent 2010:loc.5611). He (Tennent 2010:loc.5448) calls missionaries 'heralds of the New Creation', announcing and embodying the in-breaking of the future realities of God's rule in the midst of a fallen world. Precisely because we are heralds of a kingdom that has been inaugurated but not fully consummated, we live in the constant tension between the already and the not yet of God's rule.

Wright (2014:106) affirms that, in the new creation, the ancient human mandate to look after the garden is dramatically reaffirmed. God's kingdom will come on earth through an almost evolutionary process, 'or at least until human hard work in the present world attains the result God ultimately intends' (Wright 2014:84). In Wright's eschatology, Jesus is in heaven. However, heaven is not a place in the sky, but rather God's dimension of what we think of as ordinary reality (Wright 2014:96). God's people must be 'new-creation people here and now, giving birth to signs and symbols of the kingdom on earth as in heaven' (Wright 2014:106) - God's agents participating in God's mission in the renewal of the present. This is exactly the reason why Christians should have a passion for ecological work, for putting the world to rights insofar as we can right now. If this is denied, 'either the goodness of creation or the power of God in the resurrection and the Spirit, and quite possibly both' (Wright 2014:94) are denied.

\section{Eschaton in ecumenism}

One of the research goals was to establish whether an eschatological orientation to ecology and 'eco-theology' can 
be identified in The Accra Confession (2004), the Cape Town Commitment (2010) and TTL (2013).

As has been previously stated, The Accra Confession (2004) was the result of a 15-year process 'in recognition of the increasing urgency of global economic injustice and ecological destruction'. As a part of the confession, much time was devoted to a study of the current situation the world finds itself in, then described as (WARC 2004):

Resource-driven wars claim the lives of millions, while millions more die of preventable diseases. The HIV and AIDS global pandemic afflicts life in all parts of the world [...] The policy of unlimited growth among industrialized countries and the drive for profit of transnational corporations have plundered the earth and severely damaged the environment [...] Life forms and cultural knowledge are being patented for financial gain. (p. 1)

Their answer (WARC 2004) to the situation, and the threat presented by neo-liberal economic globalisation:

Speaking from our Reformed tradition and having read the signs of the times, the General Council of the World Alliance of Reformed Churches affirms that global economic justice is essential to the integrity of our faith in God and our discipleship as Christians. (p. 2)

This statement is further strengthened by the following commitment (WARC 2004):

We believe that God is a God of justice [...] God calls for just relationships with all creation [...] We are called to stand against any form of injustice in the economy and the destruction of the environment, 'so that justice may roll down like waters, and righteousness like an ever-flowing stream' (Am 5:24). (p. 3)

Although there are a few brief references to what can be described as an eschatological approach to mission as 'ecotheology', Lausanne III does not focus in detail on this orientation. However, in the discussion on the earth we must love, Lausanne III (2011:13) does refer to God's redemptive purpose for all creation. The conclusion (Lausanne III 2011) has a clear statement:

So we love the world in holy longing for the redemption and renewal of all creation and all cultures in Christ, the ingathering of God's people from all nations to the ends of the earth, and the ending of all destruction, poverty, and enmity. (p. 15)

TTL departs from a Trinitarian point of view, and understands the life-giving mission of God as a renewal of the whole creation (Keum 2013:4): 'Eco-justice cannot be separated from salvation, and salvation cannot come without a new humility that respects the needs of all life on earth' (Keum 2013:11). As the whole oikoumene is interconnected in God's web of life, the ultimate restoration of life includes all of creation. The 'church is a gift of God to the world for its transformation towards the kingdom of God. Its mission is to bring new life and announce the loving presence of God in our world' (Keum 2013:7).

TTL has a particular pneumatological focus, and describes the mission of God primarily in terms of the mission of the Spirit under four headings: Spirit of mission, Spirit of liberation, Spirit of community, and Spirit of Pentecost (Keum 2013:7). It refers to the 'Spirit's economy in creation' as part of the Spirit's mission for a new heaven and a new earth (Keum 2013:8). The document affirms that the mission of God's Spirit is to renew the whole of creation (Keum 2013:38). The Spirit allows us to taste life in its fullness and brings newness and change to the places and times of our personal and collective journeys (Keum 2013:14). The church is the 'eschatological coming together (synaxis) of the people of God in God's kingdom', a sign of hope, and the expression of the kingdom of God, a 'glimpse and foretaste of it' (Keum 2013:9, 21). It must be noted that TC also has a similar focus: the church manifests the newness of life given by Christ and, in doing so, anticipates the Kingdom already present in him (WCC 2013:38).

The very last paragraph of TTL (Keum 2013) concludes:

The Triune God invites the whole creation to the Feast of Life, through Jesus Christ who came 'that they may have life, and may have it in all its fullness' (Jn 10:10, REB), through the Holy Spirit who affirms the vision of the reign of God: 'Behold, I create new heavens and a new earth!' (Is 65:17, KJV). We commit ourselves together in humility and hope to the mission of God, who recreates all and reconciles all. And we pray, 'God of Life, lead us into justice and peace!' (p. 40)

\section{Wrapping up}

Ecology is about life. Mission is about the gospel of Jesus Christ. And the gospel is also about life (Loader 1991:46-47). The new life promised by the gospel is life in fullness. This is a reality that is already present in the reign of the risen Christ in his kingdom, and this structures and forms the life-giving mission of the church. So, what the church does in the present matters into God's future (see also Wright 2014:105). As The Accra Confession (WARC 2004) so eloquently puts it:

Now we proclaim with passion that we will commit ourselves, our time and our energy to changing, renewing and restoring the economy and the earth, choosing life, so that we and our descendants might live (Dt 30:19). (p. 5)

\section{Conclusion}

The way forward in the process of life-giving mission is discernment. Kim (2009:34) says discernment is the first act of mission. The church, as a community of followers called by the Spirit on a journey of mutual discernment, must discern where the Spirit is working to be able to join in. Thus, the skill of discernment is the door to new life and the startingpoint of the renewal of faith communities. It calls forward prophets, who proclaim their message on the basis of an act of spiritual discernment, which enables them to visualise the future consequences of a particular way of acting in the present (Conradie 2008:101), as well as the life-giving alternatives of God's life-giving reign. Missiology must extend the claims and realities of the new creation into the present order (Tennent 2010:1oc.5615). 
Mission and ecology is about life. Mission and salvation does have ecological dimensions. The polarity between creation and end times can be solved in an approach that recognises the important orientation towards creation as well as the recreation of the whole of God's household. Faithful discernment opens our eyes to the fact that we do not live in a closed house (oikos), but in one with windows open towards eternity (see also Conradie 2006:165-166) - earth as the oikodomene of God.

An overview of recent ecumenical documents showed a particular emphasis on the church's mission to participate in God's restoration of his whole oikodomene. The gospel is all about the restoration of God's rule over all of creation. In the words of Pope Francis, we must take charge of this home entrusted to us, so that we can protect and serve it (Francis 2015:69). On the way forward, missiology can contribute to ecodomy by bringing together reflection on creation and the environment with salvation. This will include missiological reflection on creation theology, social ecology, eco-justice and eco-spirituality.

\section{Acknowledgements Competing interests}

The author declares that he has no financial or personal relationships that may have inappropriately influenced him in writing this article.

\section{References}

Bevans, S.B., 1992, Models of contextual theology, Orbis Books, Maryknoll.

Bevans, S.B. \& Schroeder, R.P., 2004, Constants in context: A theology for mission today, Orbis Books, Maryknoll.

Bookless, D., 2008, 'To strive to safeguard the integrity of creation and sustain and renew the life of the earth (ii)', in A. Walls \& C. Ross (eds.), Mission in the 21st century. Exploring the five marks of global mission, pp. 94-104, Darton, Longman \& Todd, London.

Bosch, D.J., 1991, Transforming mission: Paradigm shifts in theology of mission, Orbis, New York.

Bosch, D.J., 1995, Believing in the future: Toward a missiology of Western culture, Trinity Press, Valley Forge.

Conradie, E.M., 2006, Waar op dees aarde vind mens God?, Lux Verbi BM, Wellington.

Conradie, E.M., 2008, The church and climate change, Cluster, Pietermaritzburg.

Conradie, E.M. (ed.), 2013, 'Notions and forms of ecumenicity: Some South African perspectives', in E.M. Conradie (ed.), South African perspectives on notions and forms of ecumenicity, pp. 13-76, Sun Press, Stellenbosch.

Coorilos, G.M., 2014, 'Mission towards fullness of life', International Review of Mission 103(1), 39-46. http://dx.doi.org/10.1111/irom.12037

DeWitt, C.B., 2008, 'To strive to safeguard the integrity of creation and sustain and renew the life of the earth (i)', in A. Walls \& C. Ross (eds.), Mission in the 21st century. Exploring the five marks of global mission, pp. 84-93, Darton, Longman \& Todd, London.

Du Preez, J., 1991, 'Reading three "enthronement psalms" from an ecological perspective', Missionalia 19(2), 122-130.
Edinburgh World Mission Conference, 2010, Common call, issued by the Edinburgh 2010 Centennial World Missionary Conference, 02-06 June, viewed 25 June 2015, 2010 Centennial World Missionary Conference, 02-06 June, viewed 25 June 2015, from http://www.edin

Flett, J.G., 2010, The witness of God: The Trinity, missio Dei, Karl Barth, and the nature of Christian community, Eerdmans, Grand Rapids.

Francis, St., 2015, Encyclical letter Laudato Si' of the holy father Francis on care for our common home, viewed 25 June 2015, from http://w2.vatican.va/content/ francesco/en/encyclicals/documents/papa-francesco_20150524_enciclicalaudato-si.html

Goheen, M.W., 2014, Introducing Christian mission today. Scripture, history and issues, IVP Academic, Downers Grove.

Hastings, R., 2012, Missional God, missional church. Hope for re-evangelizing the west, Kindle edn., IVP Academic, Downers Grove.

Hoekendijk, J.C., 1950, 'The call to evangelism', International Review of Mission 39 162-175. http://dx.doi.org/10.1111/j.1758-6631.1950.tb01672.x

Hulley, L.D., 1991, 'Justice, peace and the integrity creation: Some ethical comments', Missionalia 19(2), 131-143.

Keum, J. (ed.), 2013, Together towards Life: Mission and evangelism in changing landscapes. With a practical guide, World Council of Churches Publications, Geneva.

Kim, K., 2009, Joining in with the Spirit. Connecting world church and local mission, Epworth, London.

Kritzinger, J.J., 1991, 'Mission, development and ecology', Missionalia 19(1), 4-19.

Kritzinger, J.J., Meiring, P.G.J. \& Saayman, W.A., 1994, On being witnesses, Orion, Halfway House.

Kritzinger, J.N.J. \& Saayman, W.A., 2011, David J Bosch. Prophetic integrity, cruciform praxis, Cluster, Dorpspruit.

Kritzinger, K., 2011, “'Mission as..." must we choose', Missionalia 39(1/2), 32-59.

Laferton, C., 2010, 'Christians have a "responsibility" to tackle environmental crisis', report on Lausanne III - International Congress on World Evangelization, Cape Town, 16-25 October, viewed 25 June 2015, from http://www.lausanne.org/ gatherings/related/environmental-crisis

Lausanne III., 2011, 'Cape Town Commitment', Lausanne III - International Congress on World Evangelization, Cape Town, 16-25 October 2010.

Loader, J.A., 1991, 'Life, wonder and responsibility: Some thoughts on ecology and Christian mission', Missionalia 19(1), 44-56.

Meiring, P.J.G., 1991, 'The Greens - Avant-garde missionaries?', Missionalia 19(3), 192-202.

Niemandt, C.J.P., 2011, '“Blogging” David Bosch and transforming mission', Missionalia 39(1/2), 60-81.

Noort, G., 2013, '“So what?" - Dutch responses to the new mission statement', International Review of Mission 102(2), 191-198. http://dx.doi.org/10.1111/ irom. 12020

Robinson, P.J., 1991, 'Integrity of creation and Christian mission', Missionalia 19(2), 144-153.

Skreslet, S.H., 2012, Comprehending mission: The questions, methods, themes, problems, and prospects of Missiology, Orbis Books, Maryknoll.

Tennent, T.C., 2010, Invitation to world missions: A trinitarian missiology for the twenty-first century, Kregel, Grand Rapids.

Van Gelder, C. \& Zschelle, D.J., 2011, The missional church in perspective: Mapping trends and shaping conversations, Baker Academic, Grand Rapids.

Walls, A. \& Ross, C. (eds.), 2008, Mission in the 21st century. Exploring the five marks of global mission, Darton, Longman \& Todd, London.

World Alliance of Reformed Churches (WARC), 2004, 'Covenanting for justice in the economy and the earth', paper presented at the 24th General Council, Accra, Ghana, 30 July - 13 August, viewed 25 June 2015, from http://d3n8a8pro7vhmx. cloudfront.net/unitedchurchofchrist/legacy_url/395/covenanting-for-justice-incloudfront.net/unitedchurchofchrist/legacy $u$ th
the-economy-and-the-earth.pdf?1418423759

World Council of Churches (WCC), 2013, Resource book. WCC 10th Assembly, Busan 2013, WCC Publications, Geneva.

Wright, C.J.H., 2006, The mission of God. Unlocking the Bible's grand narrative, InterVarsity Press, Nottingham.

Wright, C.J.H., 2010, The mission of God's people. A Biblical theology of the church's mission, Zondervan, Grand Rapids.

Wright, N.T., 2006, Evil and the justice of God, SPCK, London.

Wright, N.T., 2014, Surprised by Scripture. Engaging contemporary issues, HarperOne, London. 